\title{
The Effect of Gamma Radiation on Mechanical Properties of Biodegradable Polymers poly(3-hydroxybutyrate) and poly(3-hydroxybutyrate-co-3-hydroxyvalerate)
}

\author{
Leticia Maria Oliveira ${ }^{\mathrm{a}}$, Patricia Lopes Barros Araujo ${ }^{\mathrm{b}, \mathrm{c}}$, Elmo Silvano Araujo $^{\mathrm{b} *}$ \\ ${ }^{a}$ Universidade Federal do Vale do São Francisco - UNIVASF, Av. Antonio Carlos Magalhães, 510, \\ CEP 48902-300, Juazeiro, BA, Brasil \\ ${ }^{\mathrm{b}}$ Laboratório de Polímeros e Nanoestruturas, Departamento de Energia Nuclear - DEN, \\ Universidade Federal de Pernambuco - UFPE, Av. Prof. Luis Freire, 1000, \\ CEP 50740-540, Recife, PE, Brasil \\ 'Ambiente de Pesquisa e Desenvolvimento Molecular, Departamento de Ciências Moleculares, \\ Universidade Federal Rural de Pernambuco - UFRPE, Av. Dom Manuel de Medeiros, s/n, \\ Dois Irmãos, CEP 52171-900, Recife, PE, Brasil
}

Received: May 17, 2012; Revised: September 4, 2012

\begin{abstract}
Brazilian poly(3-hydroxybutyrate), $\mathrm{P}(3-\mathrm{HB})$, and its copolymer, poly (3-hydroxybutyrate-co-3-hydroxyvalerate), $\mathrm{P}(3-\mathrm{HB}-\mathrm{co}-3-\mathrm{HV})$ were irradiated with gamma radiation $\left({ }^{60} \mathrm{Co}\right)$ at room temperature and in the presence of oxygen. The viscosity-average molar mass (Mv) was analyzed by viscometry using an Ostwald-type capillary viscometer. Both polymers showed a decrease in molar mass with the increase in dose, reflecting that random main chain scissions occurred. The value $G$ (scissions $/ 100 \mathrm{eV}$ of energy transferred to the system) and the parameter $\alpha$ (scissions per original molecule) were also determined. Mechanical properties decrease with the increase in dose, revealing that $\mathrm{P}(3-\mathrm{HB})$ underwent significant changes, especially at doses higher than $50 \mathrm{kGy}$. Tensile at break and impact resistance properties were the most affected by radiation, while the elastic modulus remained virtually unaltered up to $100 \mathrm{kGy}$ dose.
\end{abstract}

Keywords: gamma irradiation, $P H B, P H B$-co-HV, mechanical properties

\section{Introduction}

Poly(3-hydroxybutyrate) (P(3-HB)) and its copolymer, poly (3-hydroxybutyrate-co-3-hydroxyvalerate) ( $\mathrm{P}(3-\mathrm{HB})-\mathrm{co}-3-\mathrm{HV})$, are biodegradable thermoplastic polymers generally referred to as Poly(hydroxyalcanoates) (PHA's). These polymers are synthesized by microorganisms cultivated in the presence of excess carbon sources such as glucose, sucrose and fructose, and in the restricted presence of other nutrients, such as nitrogen ${ }^{1,2}$. Due to their characteristics, $\mathrm{P}(3-\mathrm{HB})$ and $\mathrm{P}(3-\mathrm{HB}-\mathrm{co}-3-\mathrm{HV})$ can be largely used in applications that range from domestic utensils $^{3}$ and packaging ${ }^{4-6}$ to material for medical devices ${ }^{7-10}$, given their good mechanical, thermal and biocompatibility characteristics.

$\mathrm{P}(3-\mathrm{HB})$ is a linear and stereoregular aliphatic polyester (Figure 1), synthesized and accumulated for energy storage by a number of bacteria in the form of intracellular grains ${ }^{1,11}$. The biotechnological processes for the fermentative production of $\mathrm{P}(3-\mathrm{HB})$ and $\mathrm{P}(3-\mathrm{HB}-\mathrm{co}-3-\mathrm{HV})$ by strains of the bacterium Wautersia eutropha were established in the 1970's and resulted in materials for manufacturing of various products ${ }^{12}$.

Although $\mathrm{P}(3-\mathrm{HB})$ presents good ductility after molding, ageing process frequently provokes embrittlement, probably caused by progressive crystallization upon

*e-mail: esa@ufpe.br ambient temperature storage ${ }^{13}$. Many approaches have been presented to solve rigidity problem in $\mathrm{P}(3-\mathrm{HB})$. Among them, copolymerization of 3-hydroxybutyrate with a variety of monomers, such as 3-hydroxyvalerate (3-HV), to give $\mathrm{P}(3-\mathrm{HB}-\mathrm{co}-3-\mathrm{HV})$, and 3-hydroxyhexanoate (3-HHx), to yield $\mathrm{P}(3-\mathrm{HB}-\mathrm{co}-3-\mathrm{HHx})$, allowed these copolymers to present improved mechanical properties when compared to $\mathrm{P}(3-\mathrm{HB})$ homopolymer, hence, becoming commercially attractive enough to enter in large-scale production ${ }^{14}$.

Some of $\mathrm{P}(3-\mathrm{HB})$ characteristics give this polymer a wide variety of applications. Its viscosity-average molar mass $\left(\mathrm{M}_{\mathrm{w}}\right)$ varies from $10^{4}$ to $10^{6} \mathrm{~g} \cdot \mathrm{mol}^{-1}$, with polydispersity index around 2. The glass transition temperature $\left(\mathrm{T}_{\mathrm{g}}\right)$ is $\sim 4{ }^{\circ} \mathrm{C}$, while the melting temperature $\left(\mathrm{T}_{\mathrm{m}}\right)$ is $\sim 175^{\circ} \mathrm{C}$. The densities of crystalline and amorphous $\mathrm{P}(3-\mathrm{HB})$ are 1.26 and $1.18 \mathrm{~g} . \mathrm{cm}^{-3}$, respectively. Mechanical properties, like Young's modulus (3.5 GPa) and tensile at break (43 MPa), present values which are close to those found for isotactic polypropylene (iPP) ${ }^{11}$.

One of the most promising PHA's applications is medical devices. FDA approval of poly(4-hydroxyhybutyrate) $(\mathrm{P}(4-\mathrm{HB}))$ for surgical sutures ${ }^{15}$ and meshes ${ }^{16}$ in 2007 might pave the way for more specialized uses ${ }^{17}$. In this context, assessing the influence of sterilization methods in the properties of $\mathrm{P}(3-\mathrm{HB})$ and other PHA's is of extreme 
importance. At the present, radiosterilization is the technique of choice for many polymer medical devices ${ }^{18-21}$, especially when processing closed packaged products or materials prone to absorb/adsorv chemical sterilants. However, irradiated polymers may undergo physicochemical changes such as embrittlement, discoloration, odor generation, stiffening, softening, and alterations in chemical resistance or melting temperature. These changes results, primarily, due to main chain scission and cross-linking of macromolecules generated by interactions with gamma rays ${ }^{22}$.

Radiolysis mechanism for some polyesters, including $\mathrm{P}(3-\mathrm{HB})$ and $\mathrm{P}(3-\mathrm{HB}-\mathrm{co}-3-\mathrm{HV})^{23,24}$, poly (lactide-co-glycolide) (PLGA) $)^{25,26}$ and polyethylene adipate $(\mathrm{PEA})^{27}$ were investigated by electron paramagnetic resonance (EPR) at low temperature. Many similarities were found in the nature of radicals formed during irradiation process. EPR data collected under oxygen-free atmosphere suggest massive occurrence of main chain scissions and minor contribution of side-chain elimination. A tentative cationic mechanism for $\mathrm{P}(3-\mathrm{HB})$ and $\mathrm{P}(3-\mathrm{HB}-$ co-3-HV) is shown in Figure 2. The primary event is the abstraction of an electron by Compton Effect ${ }^{28}$, with the generation of a radical cation $\mathrm{II}^{25}$. Proton elimination and electrons rearrangements lead to alpha-ester radical $\mathrm{III}^{25,27}$. Main chain scission might occur through beta homolysis of III to give a stable vinyl end group in IV and a radical carboxyl in $\mathrm{V}$, which undergoes elimination of a neutral
$\mathrm{CO}_{2}$ molecule, to yield a macromolecular fragment bearing a methylene radical end group (VI). Additional experimental supporting data to this mechanism relies on the observation of volatile products released during irradiation process, with the prevalence of $\mathrm{CO}$ and $\mathrm{CO}_{2}$ but only small amounts of methane, ethane and propane ${ }^{23}$.

Table 1 shows the effects of gamma radiation on the mechanical properties of $\mathrm{P}(3-\mathrm{HB}-\mathrm{co}-3-\mathrm{HV})$. A quite significant reduction is noted in tensile strength and elongation at break, showing that the radiation is making the material even more brittle. On the other hand, elastic modulus does not. According to Luo and Netravali ${ }^{29}$, the most significant scissions occur in the amorphous fraction. As a result, properties related to break and deformation are more affected than the elastic modulus, because the modulus of elasticity is more affected by modifications in

Table 1. Effects of gamma radiation on mechanical properties of $\mathrm{P}(3-\mathrm{HB}-\mathrm{co}-3-\mathrm{HV})^{29}$.

\begin{tabular}{cccc}
\hline Dose (kGy) & $\begin{array}{c}\text { Tensile at } \\
\text { break (MPa) }\end{array}$ & $\begin{array}{c}\text { Modulus } \\
\text { of elasticity } \\
(\mathbf{G P a})\end{array}$ & $\begin{array}{c}\text { Elongation at } \\
\text { break }(\%)\end{array}$ \\
\hline 0 & $31.69 \pm 0.43$ & $1.90 \pm 0.05$ & $3.52 \pm 0.43$ \\
100 & $24.24 \pm 1.24$ & $1.91 \pm 0.08$ & $1.75 \pm 0.20$ \\
250 & $12.57 \pm 1.07$ & $1.87 \pm 0.05$ & $0.73 \pm 0.08$ \\
\hline
\end{tabular}

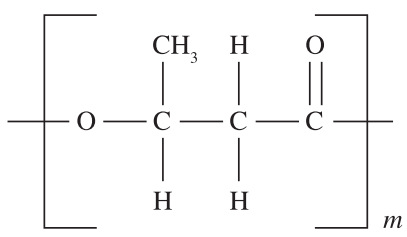

(a)

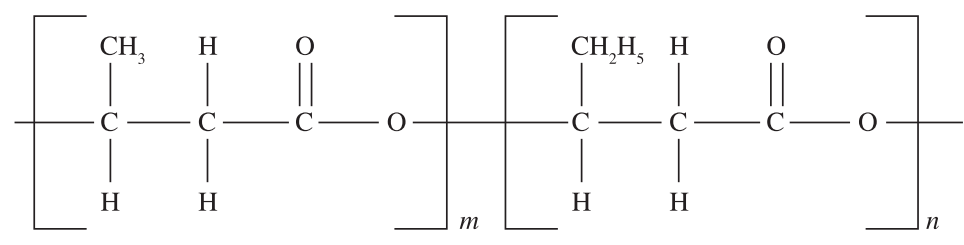

(b)

Figure 1. Chemical structures of a) poly(3-hydroxybutyrate); b) poly(3-hydroxybutyrate-co-3-hydroxyvalerate).

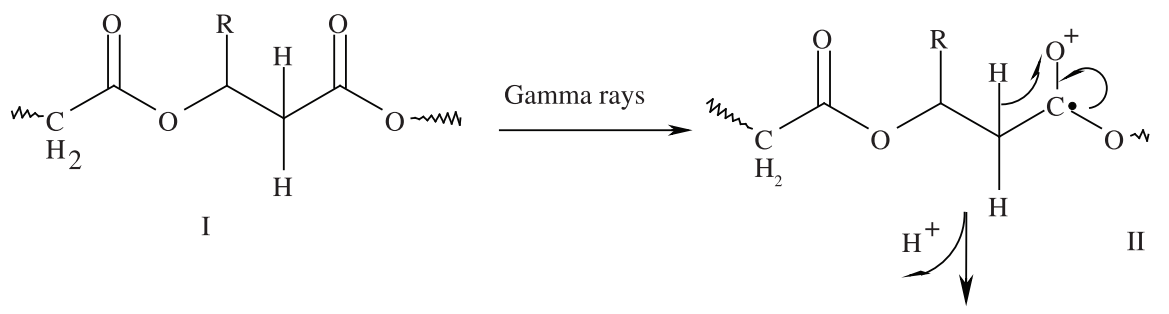<smiles>[Y][O+][O-]</smiles><smiles>[R]C=CC(=O)ONCCC</smiles><smiles>[R]C(COC(=O)CC)CC(=O)OC</smiles>

V<smiles>[CH2+]CC(=O)OC(C)=O</smiles>

Figure 2. Radiolysis mechanism of Poly (hydroxyalcanoates). $\mathrm{R}=-\mathrm{CH}_{3}, \mathrm{CH}_{2} \mathrm{CH}_{3}$. 
the crystalline rather than in the amorphous region. More recently, Hermida et $a .^{30}$ reported the effects of gamma irradiation on the mechanical properties of $\mathrm{P}(3-\mathrm{HB})$ and $\mathrm{P}(3-\mathrm{HB}-\mathrm{co}-3-\mathrm{HV})$ (12\% of 3 -HV) films in doses up to $80 \mathrm{kGy}$. No major alterations where found in tensile modulus and tensile at break in doses up to $20 \mathrm{kGy}$. Nevertheless, when irradiated up to $80 \mathrm{kGy}$, both polymers underwent reduction of $41 \%$ in tensile strength.

Mechanical properties correlate with the crystallization conditions, i.e., after quenching from the melt, small-grain spherulites are formed, but when cooled slowly spherulites with large cracks are formed. El-Hadi et al. ${ }^{31}$ studied the influence of the morphology and glass temperature on mechanical properties (elongation, stress, impact strength). According to these authors, $\mathrm{P}(3-\mathrm{HB})$ is a hard and brittle polymer, its elongation at break is less than $10 \%$, its modulus and fracture stress are $1.7 \mathrm{GPa}$ and $35 \mathrm{MPa}$, respectively. $\mathrm{P}(3-\mathrm{HB}-\mathrm{co}-3-\mathrm{HV})$ is also brittle, its elongation at break is less than $15 \%$, its modulus and fracture stress are $1.2 \mathrm{GPa}$ and $25 \mathrm{MPa}$.

In the present work, the $\mathrm{P}(3-\mathrm{HB})$ and its copolymer $\mathrm{P}(\mathrm{HB}-\mathrm{co}-3-\mathrm{HV})$ were irradiated and evaluated as to the radiolytic degradation by main chain scissions reflected in molar mass reduction. Furthermore, the consequences of radiolysis on the mechanical properties are discussed. While most reports in literature investigated film samples, our work focused on test specimens results, bring the knowledge of gamma-irradiation effects on $\mathrm{P}(3-\mathrm{HB})$ and its copolymer $\mathrm{P}(3-\mathrm{HB}-\mathrm{co}-3-\mathrm{HV})$ a step forward in terms of performance estimations aiming future practical applications.

\section{Experimental}

\subsection{Material}

In the present work the effects of gamma radiation on samples of $\mathrm{P}(3-\mathrm{HB})$ and $\mathrm{P}(3-\mathrm{HB}-\mathrm{co}-3-\mathrm{HV})$ containing $6.3 \mathrm{~mol} \%$ of $3-\mathrm{HV}$, produced by the bacterium Wautersia eutropha, were analyzed. The samples were kindly provided by PHB Industrial S.A., owner of the brand Biocycle ${ }^{\circledR}$.

Powder samples used as received and after reprecipitation from chloroform with hexane as non-solvent. Alternatively, samples were washed with hydrochloric acid $(\mathrm{HCl})$ 0.1 mol. $\mathrm{L}^{-1}$, then water, and vacuum dried under a $150 \mathrm{w}$ infrared light for over a week. These procedures aimed the elimination of processing additives, along with other possible impurities present, such as oligomers or bacterial cell wall residues.

The films were prepared from powder samples dissolved in chloroform by casting polymer solutions $(0.8 \mathrm{~g}$ of $\mathrm{P}(3-\mathrm{HB}) 1.8 \mathrm{~g}$ of $\mathrm{P}(3-\mathrm{HB}-\mathrm{co}-3-\mathrm{HV})$ to $20 \mathrm{~mL}$ of chloroform) onto Petri dishes followed by slow evaporation of the solvent at room temperature. Free-standing films, presenting approximately $90 \mu \mathrm{m}$ in thickness, were obtained.

The test specimen samples (dimensions $150 \times 20 \times 3 \mathrm{~mm}$ ), were produced from Lot 81 , according to ISO R 179 by injection process using an injection machine, brand PIC, model PIC 62. These test specimens were assayed as supplied by the manufactures, with their original additive formulation.

\subsection{Viscosity-average molar mass}

The viscosity of the samples was calculated from the relative viscosity $\left(\eta_{\text {rel }}\right)$ using chloroform as solvent, in an Ostwald-type capillary viscometer, No. 50, immersed in a water bath at $30 \pm 0.5^{\circ} \mathrm{C}$.

The relative viscosity was then obtained from the relation $\eta_{\text {rel }} \approx \mathrm{t} / \mathrm{t}_{0}$, for a regime of dilute solution where the densities of the solution and of the solvent are about the same.

Here, $\mathrm{t}_{\text {and }} \mathrm{t}_{0}$ are, respectively, the solution and solvent flow times, necessary for the liquid to pass through the two viscometer menisci marks.

The relative viscosity was determined as an average of at least eight flow time measurements for each solution. To calculate the average only the measurements with precision of $1 \%$ were considered.

After obtaining the relative viscosity, the specific viscosity $\left(\eta_{\text {esp }}=\eta_{\text {rel }}-1\right)$ and the reduced viscosity $\left(\eta_{\text {red }}=\eta_{\text {esp }} / C\right)$, C being the concentration of the solution, were calculated. The intrinsic viscosity was determined by the reduced viscosity extrapolation curve $\left([\eta]=\lim _{\mathrm{c}-0} \eta_{\mathrm{red}}\right)$ plotted by the concentration function.

The intrinsic viscosity, $[\eta]$, is a function of the molar mass of the polymer in solution, the polymer-solvent system, and the temperature.

Huggins proposed a relation between reduced viscosity, $\eta_{\text {red }}$, and concentration, c, for dilute polymeric solutions, or solutions with densities very close to the density of the solvent $^{32}$. These conditions are satisfied in $1<\eta_{\text {rel }}<2$.

$\eta_{\text {red }}=[\eta]+K_{H}[\eta]^{2} c$

where $\mathrm{K}_{\mathrm{H}}$ is a proportionality constant with value close to 0.4 for a large variety of polymer-solvent systems.

Equation 1 represents a straight line on the plot of $\eta_{\text {red }}$ versus $\mathrm{c}$, and $[\eta]$ can be obtained by extrapolation to zero concentration.

The choice of the two concentration levels is based on Huggins conditions, where the lower limit of relative viscosity is higher and close to 1 , while the upper limit is lower and close to 2 .

Viscosity tests were carried out with sample sets 1 and 2, under powder or film forms. In this case, doses ranged from 5 to $300 \mathrm{kGy}$. Viscometric studies were also carried out in solutions prepared from samples molded as test specimens.

With the values for intrinsic viscosities, the viscosity-average molar mass $\left(\mathbf{M}_{\mathrm{v}}\right)$ is easily obtained by means of the Mark-Houwink relation ${ }^{33}$ :

$[\eta]=\mathrm{K}\left(\mathrm{M}_{\mathrm{V}}\right)^{a}$

where the constants $\mathrm{K}$ and $a$, calculated by Akita et al..$^{34}$ for the chloroform-P(3-HB) system at $30{ }^{\circ} \mathrm{C}$ are $\mathrm{K}=1.18 \times 10^{-4} \mathrm{dL} \cdot \mathrm{g}^{-1}$ and $a=0.78$.

The degradation degree $\mathrm{G}$, which represents the number of scissions in the main chain for each $100 \mathrm{eV}$ of absorbed energy, is obtained by means of the Equation $3^{35}$ :

$10^{6} / \mathrm{Mv}=10^{6} / \mathrm{Mv}_{0}+0.0548 \mathrm{GD}$

where $\mathrm{D}$ is the absorbed dose of irradiation in $\mathrm{kGy}$ and $\mathrm{G}$ the degree of degradation (number of scissions/100 eV of absorbed energy). 
This parameter is obtained from the slope of the curve $10^{6} / \mathrm{M}_{\mathrm{V}} \times \mathrm{D}(\mathrm{kGy})$, in the interval where the inverse of the molar mass is linear in relation to the dose. This condition represents the dose interval where the scissions occur at random in the main chain.

\subsection{Irradiation}

The samples were irradiated at the Institute of Energy and Nuclear Research - IPEN-CNEN/SP with doses that varied from 5 to $300 \mathrm{kGy}$. A Gammacell-type ${ }^{60} \mathrm{Co}$ source was used at dose rates of $4.3 \mathrm{kGy} / \mathrm{h}$ for the irradiation of $\mathrm{P}(3-\mathrm{HB})$ test specimens and $3.6 \mathrm{kGy} / \mathrm{h}$ for the irradiation of polymer films. In both cases the irradiation occurred at $25^{\circ} \mathrm{C}$. For comparison, as-received $\mathrm{P}(3-\mathrm{HB})$ samples were also irradiated, in powder form, at $3.6 \mathrm{kGy} / \mathrm{h}$ dose rate and $25^{\circ} \mathrm{C}$.

\subsection{Mechanical tests}

The tensile tests were performed according to ASTM D-882 Standards in a universal testing machine EMIC, DL line, maximum force of $500 \mathrm{~N}$, under the following conditions: temperature $25^{\circ} \mathrm{C}$, claw speed $50 \mathrm{~mm} / \mathrm{min}$ and distance between claws $110 \mathrm{~mm}$. The tests were done with non-irradiated test specimens and test specimens irradiated at $5,15,25,35,50,100$ and $200 \mathrm{kGy}$ doses.

The impact-strength tests were performed according to ASTM D-256 in an Izod impact tester (Hammer 2J), with a hammer impact speed of $3.46 \mathrm{~m} / \mathrm{s}$ and an approximate notch depth of $2.54 \mathrm{~mm}$, in $60 \times 10 \times 3 \mathrm{~mm} \mathrm{P}(3-\mathrm{HB})$ test specimens irradiated 5, 15, 25, 35, 50 and $100 \mathrm{kGy}$ doses.

\section{Results and Discussion}

Table 2 shows the values for $\mathrm{M}_{\mathrm{v} 0}$ for as-received and reprecipitated samples. The small difference in molar mass between the two samples may be related to the elimination of small structures that might interfere in the flow properties the solution.

For viscometric analyses carried out with as-received samples of $\mathrm{P}(3-\mathrm{HB})$ and $\mathrm{P}(3-\mathrm{HB}-\mathrm{co}-3-\mathrm{HV})$ in powder form, the $\mathrm{M}_{\mathrm{v} 0}$ values were $3.63 \times 10^{5} \mathrm{~g} / \mathrm{mol}$ and $1.06 \times 10^{5} \mathrm{~g} / \mathrm{mol}$, respectively.

Figure 3 shows the reciprocal of the molar mass of films prepared with reprecipitated or as-received $\mathrm{P}(3-\mathrm{HB})$, from non-irradiated material or irradiated at 5,15 or $25 \mathrm{kGy}$. A lower $\mathrm{G}$ value of 5.4 scissions/100 eV found in the reprecipitated $\mathrm{P}(3-\mathrm{HB})$ suggest that the degradation of this sample after irradiation is less severe when compared to as-received $\mathrm{P}(3-\mathrm{HB})$ films $(\mathrm{G}$ value $=7.0$ scissions $/ 100 \mathrm{eV})$. Hence, this simple purification step helped in preventing extensive radiation damage in the homopolymer matrix. Similarly, alterations in reciprocal of the molar mass for films prepared from as-received or reprecipitated $\mathrm{P}(3-\mathrm{HB}-\mathrm{co}-3-\mathrm{HV})$ (Figure 4), in the interval of 0-25 kGy evidenced a lower susceptibility of this copolymer to radiation after reprecipitation procedure, when $\mathrm{G}$ value decreases to 7.4 scissions $/ 100 \mathrm{eV}$, while reaching 10.6 scissions/100 eV in the as-received material. In addition, a direct comparison between $\mathrm{G}$ values for $\mathrm{P}(3-\mathrm{HB}-\mathrm{co}-3-\mathrm{HV})$ and $\mathrm{P}(3-\mathrm{HB})$ suggests that the copolymer is intrinsically less resistant to radiation than the homopolymer.
As-received $\mathrm{P}(3-\mathrm{HB})$ samples in powder form were also irradiated and showed an $85 \%$ reduction in their initial molar mass at the dose of $25 \mathrm{kGy}$. In comparison, at the same dose, films casted from reprecipitated or as-received $\mathrm{P}(3-\mathrm{HB})$ showed $38 \%$ and $25 \%$ molar mass reduction, respectively. Polymer films are less susceptible to the effects of radiation when compared to the powder material, possible because the dissolution process allows impurities to be dislodged from bulk and deposited in the surface of the film during the casting process, thus trigging less degrading effects to the matrix when exposed to radiation. Alternatively, powder samples are more susceptible to photo oxidation events than film samples because of the larger contact surface of the former.

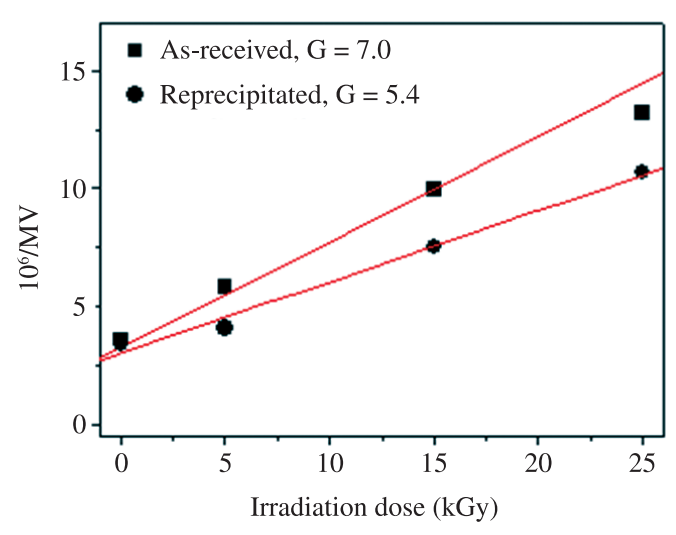

Figure 3. Reciprocal of the viscosity-average molar mass (Mv) as a function of the dose absorbed by the $\mathrm{P}(3-\mathrm{HB})$ films prepared from as-received or reprecipitated material.

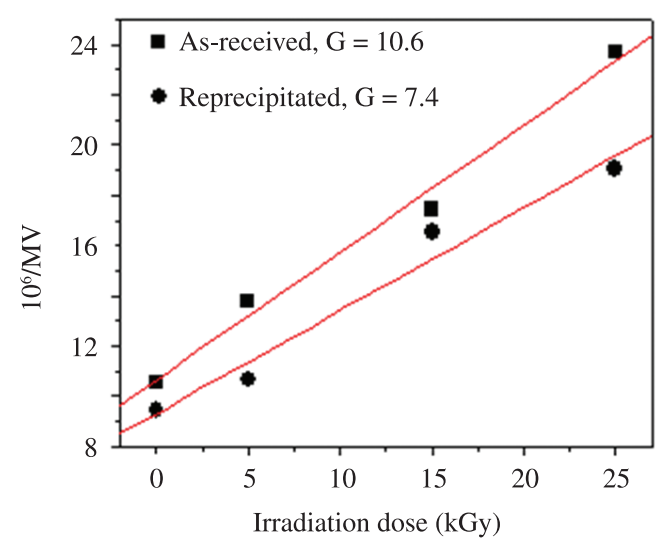

Figure 4. $10^{6} / \mathrm{M}_{\mathrm{V}}$ and $\mathrm{G}$ value (scissions $/ 100 \mathrm{eV}$ ) for $\mathrm{P}(3-\mathrm{HB}-\mathrm{co}-3-\mathrm{HV})$ irradiated films from as-received or reprecipitated samples.

Table 2. Molar mass $\left(\mathrm{M}_{\mathrm{v} 0}\right)$ of $\mathrm{P}(3-\mathrm{HB})$ and $\mathrm{P}(3-\mathrm{HB}-\mathrm{co}-3-\mathrm{HV})$ films.

\begin{tabular}{ccc} 
Sample & $\begin{array}{c}\mathbf{M}_{\mathbf{v} \mathbf{0}}\left(\mathbf{1 0}^{\mathbf{5}} \mathbf{g} / \mathbf{m o l}^{-\mathbf{1}}\right) \\
\text { (Reprecipitated film) }\end{array}$ & $\begin{array}{c}\mathbf{M}_{\mathbf{v} \mathbf{0}}\left(\mathbf{1 0} \mathbf{~} / \mathbf{m o l}^{-\mathbf{1}}\right) \\
\text { (non-treated ) }\end{array}$ \\
\hline $\mathrm{P}(3-\mathrm{HB})$ & 2.92 & 2.79 \\
$\mathrm{P}(3-\mathrm{HB}-\mathrm{co}-3-\mathrm{HV})$ & 1.05 & 0.98 \\
\hline
\end{tabular}


Viscometric studies carried out with $\mathrm{P}(3-\mathrm{HB})$ test specimens revealed $\mathrm{M}_{\mathrm{v} 0}$ equals to $2.0 \times 10^{5} \mathrm{~kg} \cdot \mathrm{mol}^{-1}$. Based on the reciprocal of $\mathrm{M}_{\mathrm{v}}$, the value $\mathrm{G}$ (scissions per $100 \mathrm{eV}$ ) was obtained. The results for low (0-25 kGy) and high doses (35-200 kGy) are shown in Figure 5. Test specimens underwent less molecular degradation than powder samples. This fact evidences the importance of initial molar mass and samples shape when assessing gamma-irradiation effects. As a consequence of their higher degradation resistance, the percentage reduction of molar mass is less pronounced for test specimens. As can be observed in Figure 6, at $5 \mathrm{kGy}$ dose, molar mass reduction was about $40 \%$. At $25 \mathrm{kGy}$, molar mass suffered a reduction of $80 \%$, and reached above $95 \%$ of reduction at $100 \mathrm{kGy}$. Table 3 summarizes the degradation parameters of $\mathrm{P}(3-\mathrm{HB})$ and $\mathrm{P}(3-\mathrm{HB}-\mathrm{co}-3-\mathrm{HV})$ at the sterilization dose. The degree of degradation $G$ (scissions/100 eV) obtained from the interval of 0-25 kGy is higher for powder than for film samples.

The small differences between films prepared from as-received or reprecipitated materials show that, at the purity stage supplied by the industry, $\mathrm{P}(3-\mathrm{HB})$ and $\mathrm{P}$ (3-HB-co-3-HV) may appear less resistant to radiation than they really are. An alternative purification step was performed in our work, in order to verify the viability of an affordable, less harsh, readily scaled-up purification method, suitable to industrial post- production procedures. We used diluted $\mathrm{HCl}$ aqueous solutions to simple wash ups in samples at the powder form. The value $\mathrm{G}$ for $\mathrm{P}(3-\mathrm{HB})$ films from samples treated with diluted $\mathrm{HCI}$ showed to be very close to that obtained for films prepared with reprecipitated $\mathrm{P}(3-\mathrm{HB})$, indicating the efficiency of this acid in removing impurities responsible for radiolysis. In the other hand, using diluted $\mathrm{NH}_{4} \mathrm{OH}$ solutions did not result in any improvements. This findings suggest than a simple, straightforward washing procedure is able to improve $\mathrm{P}(3-\mathrm{HB})$ performance when submitted to gamma irradiation, and yields approximately the same results obtained with reprecipitation with hexane from chloroform, a much less environmentally-friendly procedure. This washing procedure is easily scaled-up and may be introduced as a previous purification procedure for industrial production of radiosterilization-grade $\mathrm{P}(3-\mathrm{HB})$.

Gas Chromatography-Mass Spectrometry (GC-MS) analysis performed in methanol extracts of $\mathrm{P}(3-\mathrm{HB})$ revealed a considerable amount of fatty acids, such as lauric $(39.6 \%)$, butyric $(26.5 \%)$ and oleic acid $(20.4 \%)$, in addition, around $5 \%$ of phthalate esters were present, probably used as plastifiers ${ }^{36}$. Fatty acids might be formed during the biosynthesis process. Their composition and proportion are dependent of many factors, such as aeration rates during fermentation. Oxygen limitation frequently leads to higher contents of organic acids and other metabolites

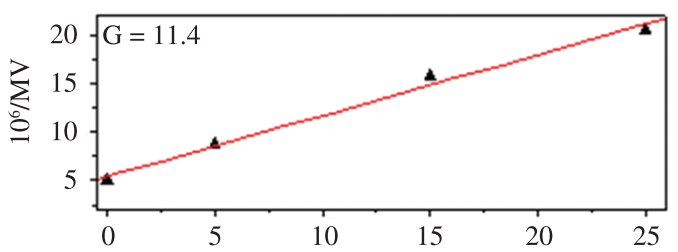

(a)

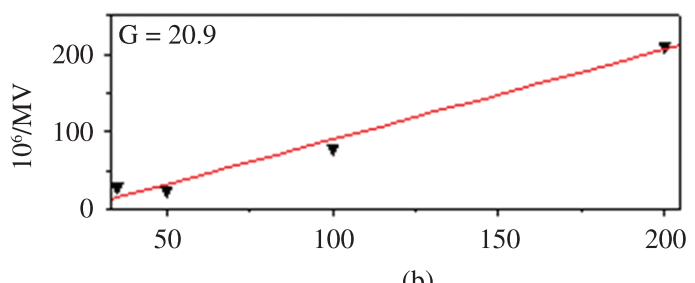

(b)

Irradiation dose (kGv)

Figure 5. Reciprocal of the molar mass $(\mathrm{Mv})$ as a function of the irradiation dose to $\mathrm{P}(3-\mathrm{HB})$ test specimens. a) $0-25 \mathrm{kGy}$; b) 35-200 kGy.

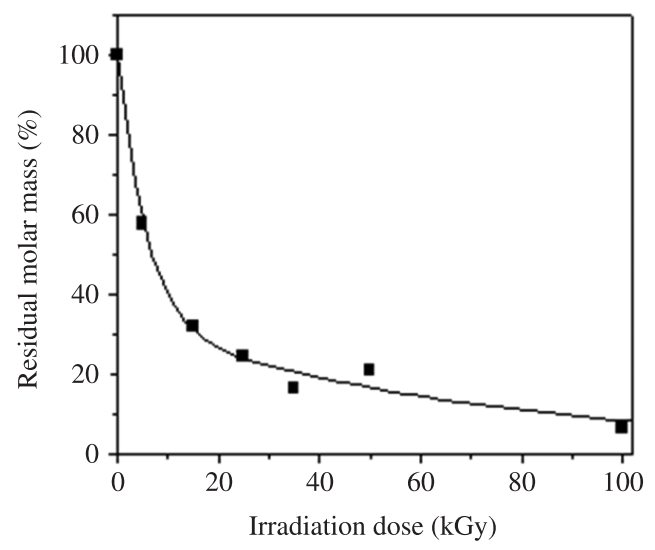

Figure 6. Residual molar mass of $\mathrm{P}(3-\mathrm{HB})$ test specimens.

Table 3. Summary of the degradation parameters for irradiated $\mathrm{P}(3-\mathrm{HB})$ and $\mathrm{P}(3-\mathrm{HB}-\mathrm{co}-3-\mathrm{HV})$.

\begin{tabular}{cccccc}
\hline Samples & Form & Treatment & $\begin{array}{c}\text { G } \\
(\mathbf{0 - 2 5} \mathbf{~ k G y})\end{array}$ & $\begin{array}{c}\text { a } \\
(\mathbf{2 5} \mathbf{~ k G y})\end{array}$ & $\begin{array}{c}\text { Reduction of } \\
\text { molar mass }(\%) \\
(\mathbf{2 5} \mathbf{~ k G y})\end{array}$ \\
\hline PHB & Powder & - & 12.9 & 6.6 & 86.8 \\
& Film & - & 7.0 & 2.64 & 72.8 \\
& Film & Reprecipitated & 5.4 & 2.12 & 67.9 \\
& Film & HCl & 5.9 & 2.27 & 65.2 \\
P(3-HB-co-3-HV) & Specimen & - & 11.4 & 3.10 & 76.7 \\
& Powder & - & 13.8 & 5.05 & 67.2 \\
& Film & - & 10.6 & 1.25 & 55.5 \\
\hline
\end{tabular}


and deprives biopolymer formation ${ }^{37}$. These by-products might be responsible for increased molecular damage observed in non-treated irradiated samples. Nevertheless, it is difficult to predict how such complex mixture behaves under irradiation. In addition, each biopolymer batch may have a different set of contaminants. Thus, performing pre-washings are recommendable or even essential in case of radiation-grade products manufacturing.

Table 4 summarizes some results gathered from literature on radiolytic degradation of $\mathrm{P}(3-\mathrm{HB})$ and $\mathrm{P}(3-\mathrm{HB}-\mathrm{co}-3-\mathrm{HV})$, caused by gamma irradiation, along with some results obtained in the present work. It must be pointed out that the samples are of different origins so, their characteristics will be different, as well.

$\mathrm{P}(3-\mathrm{HB})$ suffers scissions in its main chain with consequent changes in its mechanical properties. Considering this fact, the analyzed properties were: tensile at break, which assesses how much load is applied to the polymer at the moment of break; elongation at break, which assesses the stretchability of the polymer; modulus of elasticity, which is related to material stiffness; and impact resistance.

The mechanical behavior of non-irradiated and irradiated $\mathrm{P}(3-\mathrm{HB})$ test specimens at different doses was analyzed. The results show that the material becomes more fragile and brittle with the increase in irradiation dose. The degradation suffered due to the chain scissions under the radiation effect reflects mainly in the decrease of tensile at break and impact resistance, while the elastic modulus is the least affected by the irradiation process.

Figure 7 shows the behavior of the tensile at break as a function of the irradiation dose in $\mathrm{P}(3-\mathrm{HB})$ test specimens. At the dose of $25 \mathrm{kGy}$, the loss in tensile strength suffered by the sample was $20 \%$. On the other hand, at higher doses, as 100 and $200 \mathrm{kGy}$, the loss in this property was 40 and $75 \%$, respectively.

The behavior of the elongation at break as a function of the irradiation dose is shown in Figure 8. The change in this property is less pronounced than that observed for the tensile strength. At $25 \mathrm{kGy}$ dose, the loss in elongation at break due to radiation was $10 \%$, while at higher ones, as 100 and $200 \mathrm{kGy}$, the losses were 25 and 40\%, respectively.

In Figure 9, the behavior of the property of elastic modulus for $\mathrm{P}(3-\mathrm{HB})$ can be observed with the dose. This property did not present any significant change up to the dose of $100 \mathrm{kGy}$, with $50 \%$ loss detected after a $200 \mathrm{kGy}$ dose. This property is related to material stiffness, which means that it reflects the resistance of this material to elastic deformation. For crystalline polymers, it is common to notice milder gamma radiation effect on elastic modulus. Luo and Netravali ${ }^{29}$ stated that the property of elastic modulus is more intimately related to the crystalline content of the polymer, which is less affected by radiation than the amorphous content. This may explain why the elastic modulus is altered only at doses higher than $100 \mathrm{kGy}$ as the radiation is not able to destroy the crystalline portions, responsible for the stiffness of the material.

The property of impact resistance Izod was significantly affected by gamma radiation. In Figure 10 it can be observed that, at the $25 \mathrm{kGy}$ dose, the loss in this property was $25 \%$, while at the dose of $100 \mathrm{kGy}$ this loss was about $87 \%$. It was not possible to perform these studies with samples irradiated at a dose of $200 \mathrm{kGy}$.

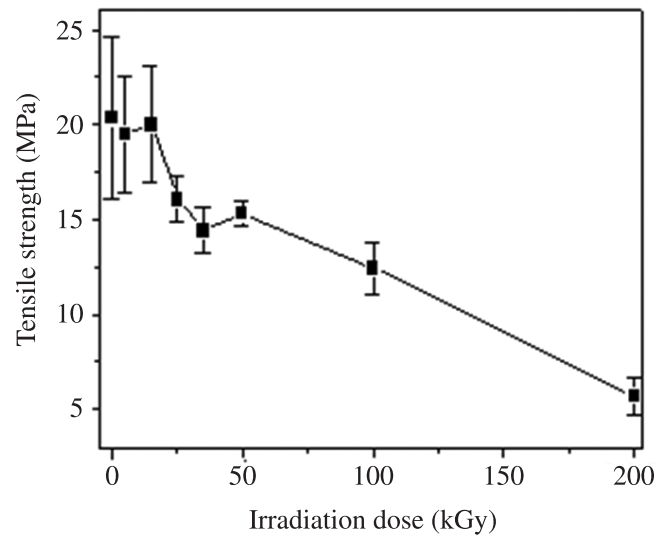

Figure 7. Tensile at break as a function of irradiation dose in $\mathrm{P}(3-\mathrm{HB})$ test specimens.

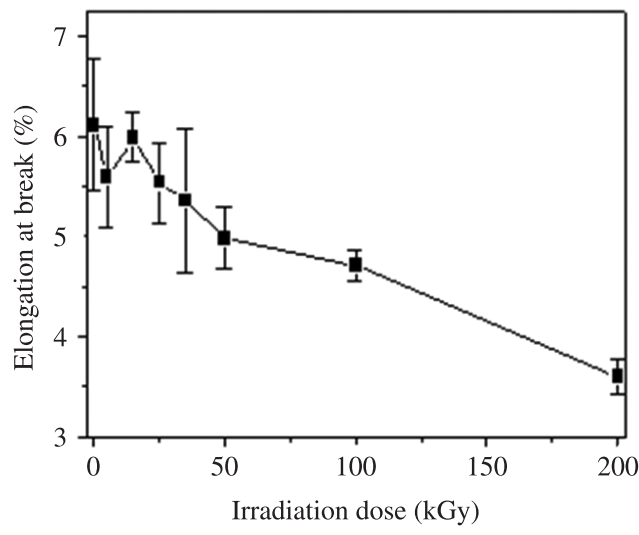

Figure 8. Elongation at break as a function of irradiation dose for $\mathrm{P}(3-\mathrm{HB})$ test specimens.

Table 4. Values $\mathrm{G}$ (scissions $/ 100 \mathrm{eV}$ ) obtained for $\mathrm{P}(3-\mathrm{HB})$ and $\mathrm{P}(3-\mathrm{HB}-\mathrm{co}-3-\mathrm{HV})$ irradiated in air.

\begin{tabular}{cccccc}
\hline \multirow{2}{*}{ Reference } & PHB Form & $\begin{array}{c}\text { P(3-HB-co-3-HV) } \\
\text { Form }\end{array}$ & $\begin{array}{c}\text { Dose Interval } \\
\text { (kGy) }\end{array}$ & $\begin{array}{c}\text { G value } \\
\text { PHB }\end{array}$ & $\begin{array}{c}\text { G value } \\
\text { P(3-HB-co-3-HV) }\end{array}$ \\
\hline$[29]$ & - & Film & $0-250$ & - & 0.9 \\
{$[38]$} & Powder & - & $0-200$ & 5.9 & - \\
{$[38]$} & Film & - & $0-200$ & 6.0 & - \\
Present work & Film & Film & $0-25$ & 5.4 & 7.4 \\
Present work & Powder & Powder & $0-50$ & 15.7 & 12.9 \\
\hline
\end{tabular}


Table 5. Results of mechanical studies in $\mathrm{P}(3-\mathrm{HB})$ test specimens.

\begin{tabular}{ccccc}
\hline Dose $(\mathbf{k G y})$ & $\begin{array}{c}\text { Tensile at break } \\
(\mathbf{M P a})\end{array}$ & $\begin{array}{c}\text { Elongation at break } \\
(\boldsymbol{\%})\end{array}$ & $\begin{array}{c}\text { Modulus of elasticity } \\
(\mathbf{G P a})\end{array}$ & $\begin{array}{c}\text { Impact resistance izod } \\
\left(\mathbf{J} / \mathbf{m}^{-1}\right)\end{array}$ \\
\hline 0 & $20.35 \pm 4.294$ & $6.11 \pm 0.65$ & $0.76 \pm 0.04$ & $27.3 \pm 0.21$ \\
5 & $19.49 \pm 3.051$ & $5.59 \pm 0.56$ & $0.79 \pm 0.03$ & $25.3 \pm 1.60$ \\
15 & $20.00 \pm 3.074$ & $5.98 \pm 0.24$ & $0.77 \pm 0.02$ & $22.2 \pm 0.63$ \\
25 & $16.06 \pm 1.223$ & $5.53 \pm 0.39$ & $0.75 \pm 0.06$ & $20.4 \pm 2.12$ \\
35 & $14.42 \pm 1.172$ & $5.35 \pm 0.71$ & $0.74 \pm 0.05$ & $17.8 \pm 1.83$ \\
50 & $15.31 \pm 0.689$ & $4.98 \pm 0.31$ & $0.81 \pm 0.07$ & $16.7 \pm 1.16$ \\
100 & $12.42 \pm 1.416$ & $4.70 \pm 0.14$ & $0.74 \pm 0.06$ & $13.1 \pm 1.57$ \\
200 & $5.68 \pm 1.01$ & $3.60 \pm 0.18$ & $0.40 \pm 0.05$ & - \\
\hline
\end{tabular}

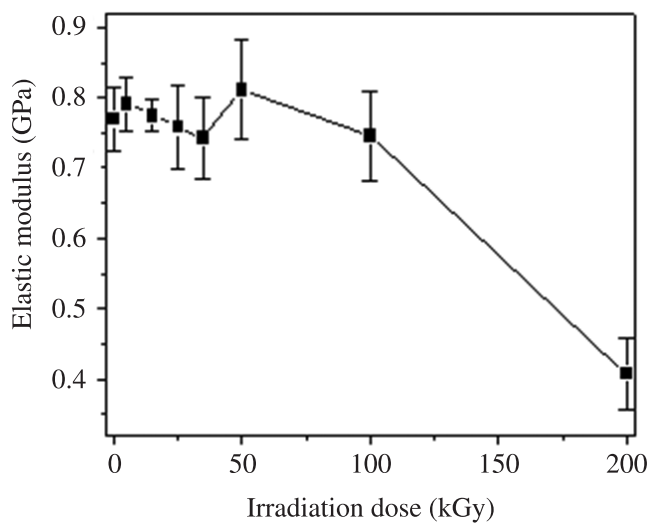

Figure 9. Elastic modulus as a function of irradiation dose for $\mathrm{P}(3-\mathrm{HB})$ test specimens.

Gamma radiation causes scissions first and predominantly in molecules of the amorphous region ${ }^{38}$. The property of tensile at break is more closely related to damages in the amorphous region of the material ${ }^{39}$. However, scissions in the linked molecules are the ones that cause the highest losses in mechanical properties to a crystalline polymer ${ }^{40}$.

The properties of tensile at break and impact resistance Izod in $\mathrm{P}(3-\mathrm{HB})$ test specimens were the most affected by radiation at sterilization dose $(25 \mathrm{kGy})$, as is shown in Table 5, while elongation at break and modulus of elasticity suffered negligible decreasing. Nevertheless, general mechanical performance of $\mathrm{P}(3-\mathrm{HB})$ samples worsens at irradiation doses higher than $100 \mathrm{kGy}$.

\section{References}

1. Holmes PA. Applications of PHB-A microbially produced biodegradable thermoplastic. Physics in Technology. 1985; 16(1):32-36. http://dx.doi. org/10.1088/0305-4624/16/1/305

2. Hazer B and Steinbuchel A. Increased diversification of polyhydroxyalkanoates by modification reactions for industrial and medical applications. Applied Microbiology and

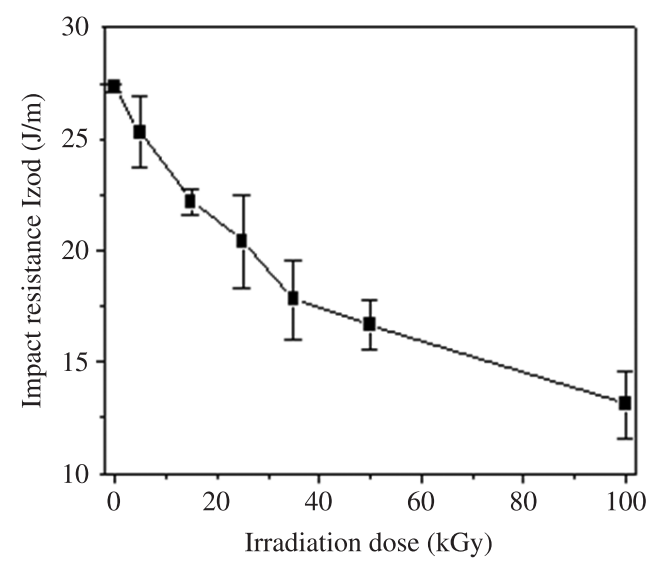

Figure 10. Impact Resistance Izod with irradiation dose for $\mathrm{P}(3-\mathrm{HB})$ test specimens.

\section{Conclusions}

Radiostability of $\mathrm{P}(3-\mathrm{HB})$ and $\mathrm{P}(3-\mathrm{HB}-\mathrm{co}-3-\mathrm{HV})$ was showed to be improved by simple purification procedures, as either reprecipitation of the samples with hexane from chloroform solutions or washing with diluted $\mathrm{HCl}$ promoted reduction in the degree of radiolytic degradation.

The mechanical studies showed that $\mathrm{P}(3-\mathrm{HB})$ properties decrease, especially at doses higher than $50 \mathrm{kGy}$. The properties of tensile at break and impact resistance were the most affected by radiation, while the property of elastic modulus remained virtually unaltered up to the dose of $100 \mathrm{kGy}$, due the presence of crystalline regions in the polymer matrix, which confer stiffness to the matrix and are less affected by irradiation than amorphous regions.

Biotechnology. 2007; 74(1):1-12. http://dx.doi.org/10.1007/ s00253-006-0732-8

3. Platt DK. Biodegradable Polymers: Market Report. Shawbury: Smithers Rapra Limited; 2006.

4. Miguel $\mathrm{O}$ and Iruin JJ. Evaluation of the transport properties of poly(3-hydroxybutyrate) and its 3-hydroxyvalerate copolymers for packaging applications. Macromolecular Symposia. 1999; 144:427-438. http://dx.doi.org/10.1002/ masy. 19991440140 
5. Bucci DZ, Tavares LBB and Sell I. PHB packaging for the storage of food products. Polymer Testing. 2005; 24(5):564-571. http://dx.doi.org/10.1016/j.polymertesting.2005.02.008

6. Modi S, Koelling K and Vodovotz Y. Assessment of PHB with varying hydroxyvalerate content for potential packaging applications. European Polymer Journal. 2011; 47(2):179-186. http://dx.doi.org/10.1016/j.eurpolymj.2010.11.010

7. Chen GQ and Wu Q. The application of polyhydroxyalkanoates as tissue engineering materials. Biomaterials. 2005; 26(33):6565-6578. http://dx.doi. org/10.1016/j.biomaterials.2005.04.036

8. Gursel I, Yagmurlu F, Korkusuz F and Hasirci V. In vitro antibiotic release from poly(3-hydroxybutyrate-co-3-hydroxyvalerate) rods. Journal of Microencapsulation. 2002; 19(2):153-164. http://dx.doi.org/10.1080/02652040110065413

9. Piskin E, Bölgen N, Egri S and Isoglu IA. Electrospun matrices made of poly(alpha-hydroxy acids) for medical use. Nanomedicine. 2007; 2(4):441-457. http://dx.doi. org/10.2217/17435889.2.4.441

10. Peng S-W, Guo X-Y, Shang G, Li J, Xu X-Y, You M et al. An assessment of the risks of carcinogenicity associated with polyhydroxyalkanoates through an analysis of DNA aneuploid and telomerase activity. Biomaterials. 2011; 32(10):2546-2555. http://dx.doi.org/10.1016/j.biomaterials.2010.12.051

11. Sudesh K, Abe H and Doi Y. Synthesis, structure and properties of polyhydroxyalkanoates: biological polyesters. Progress in Polymer Science. 2000; 25(10):1503-1555. http://dx.doi. org/10.1016/S0079-6700(00)00035-6

12. Steinbüchel A and Füchtenbusch B. Bacterial and other biological systems for polyester production. Trends in Biotechnology. 1998; 16(10):419-427. http://dx.doi. org/10.1016/S0167-7799(98)01194-9

13. De Koning GJM and Lemstra PJ. Crystallization phenomena in bacterial poly[(R)-3-hydroxybutyrate]: 2. Embrittlement and rejuvenation. Polymer. 1993; 34(19):4089-4094. http://dx.doi. org/10.1016/0032-3861(93)90671-V

14. Kosior E, Bragança RM and Fowler P. Lightweight Compostable Packaging: Literature Review. Oxon: The Waste \& Resources Action Programme; 2006. Retailer Innovation Milestone Report A.

15. Food and Drug Administration - FDA. K052225 - TephaFLEX ${ }^{\circledR}$ Surgical Suture. Available from: <www.accessdata.fda.gov/ cdrh_docs/pdf5/K052225.pdf>. Access in: 25/02/2012.

16. Food and Drug Administration - FDA. K070894 - TephaFLEX Surgical Mesh. Available from: <www.accessdata.fda.gov/ cdrh_docs/pdf7/K070894.pdf>. Access in: 25/02/2012.

17. Hazer DB, Kılıçay E and Hazer B. Poly(3-hydroxyalkanoate) $\mathrm{s}$ : Diversification and biomedical applications: A state of the art review. Materials Science and Engineering C. 2012; 32(4):637-647. http://dx.doi.org/10.1016/j. msec.2012.01.021

18. Hemmerich KJ. Polymer Materials Selection for Radiation-Sterilized Products. MDDI Medical Device and Diagnostic Industry News Products and Suppliers; 2000. Available from: <http://www.mddionline.com/print/88>. Access in: 27/02/2012.

19. American National Standards Institute - ANSI. ANSI/ AAMI/ISO 11137-1:2006: Sterilization of health care products-Radiation-Part 1: Requirements for development, validation, and routine control of a sterilization process for medical devices. ANSI; 2006.

20. American National Standards Institute - ANSI. ANSI/ AAMI/ISO 11137-2:2006: Sterilization of health care
products-Radiation-Part 2: Establishing the sterilization dose. ANSI; 2006.

21. American National Standards Institute - ANSI. ANSI/ AAMI/ISO 11137-3:2006: Sterilization of health care products-Radiation-Part 3: Guidance on dosimetric aspects. ANSI; 2006.

22. Guillet J. Polymers Photophysics and Photochemistry. New York: Cambridge University Press; 1987.

23. Carswell-Pomerantz T, Dong L, Hill DJ, O'Donnell JH and Pomery PJ. Mechanistic studies on the radiation chemistry of poly(hydroxybutyrate). In: Clough RL and Shalaby SW, editors. Irradiation of Polymers: Fundamentals and Technological Applications. Washington: ACS; 1994. chapt. 2. ACS Symposium Series 620.

24. Carswell-Pomerantz T, Hill DJ, O'Donnell JH and Pomery PJ. An electron spin resonance study of the radiation chemistry of poly(hydroxybutyrate). Radiation Physics and Chemistry. 1995; 45(5):737-744. http://dx.doi. org/10.1016/0969-806X(94)00091-W

25. Montanari L, Costantini M, Signoretti EC, Valvo L, Santucci $\mathrm{M}$, Bartolomei $\mathrm{M}$ et al. Gamma irradiation effects on poly (DL-lactictide-co-glycolide) microspheres. Journal of Controlled Release. 1998; 56(1-3):219-229. http://dx.doi. org/10.1016/S0168-3659(98)00082-0

26. Montanari L, Cilurzo F, Valvo L, Faucitano A, Buttafava A, Groppo A et al. Gamma irradiation effects on stability of poly (lactide-co-glycolide) microspheres containing clonazepam. Journal of Controlled Release. 2001; 75(3):317-330. http:// dx.doi.org/10.1016/S0168-3659(01)00401-1

27. Ravasio U, Butaffava A, Mariani M, Dondi D and Faucitano A. EPR and ab-initio study on the solid state radiolysis of aliphatic and aromatic polyesters. Polymer Degradation and Stability, 2008; 93(5):1031-1036. http://dx.doi.org/10.1016/j. polymdegradstab.2007.12.017

28. Clegg DW and Collyer AA, editors. Irradiation effects on polymers. New York: Elsevier, 1991.

29. Luo S and Netravali N. Effect of ${ }^{60} \mathrm{Co}$ gamma-radiation on the properties of poly(hydroxybutyrate-co-hydroxyvalerate). Journal of Applied Polymer Science. 1999; 73(6):1057-1067. http://dx.doi.org/10.1002/(SICI)1097-4628(19990808)73:6<1 059::AID-APP25>3.0.CO;2-Q

30. Hermida EB, Mega VI, Yashchuk O, Fernandez V, Eisenberg P and Miyazaki SS. Gamma irradiation effects on mechanical and thermal properties and biodegradation of poly (3-hydroxybutyrate) based films. Macromolecular Symposia. 2008; 263(1):102-113. http://dx.doi.org/10.1002/ masy. 200850313

31. El-Hadi A, Schnabel R, Straube E, Muller G and Henning S. Correlation between degree of crystallinity, morphology, glass temperature, mechanical properties and biodegradation of poly (3-hydroxyalkanoate) PHAs and their blends. Polymer Testing. 2002; 21(6):665-674. http://dx.doi.org/10.1016/S01429418(01)00142-8

32. Rosen SL. Fundamental principles of polymeric materials. New York: John Wiley \& Sons; 1993.

33. Billmewyer FW. Textbook of polymer science. 3rd ed. New York: John Wiley \& Sons; 1984.

34. Akita S, Einaga Y, Miyaki Y and Fujita H. Solution properties of poly(d- $\beta$-hydroxybutyrate). 1. Biosynthesis and characterization. Macromolecules. 1976; 9(5):774-778. http:// dx.doi.org/10.1021/ma60053a017 
35. Araujo ES, Khoury HJ, Silveira SV. Effects of gamma-irradiation on some properties of durolon polycarbonate. Radiation Physics and Chemistry. 1998; 53(1):79-84.

36. Oliveira LM. Efeitos da radiação gama no polímero biodegradável polihidroxibutirato e no copolímero polihidroxibutirato-co-hidroxivalerato. [Tese]. Recife: Universidade Federal de Pernambuco; 2006.

37. Du G, Chen XL and Yu J. High-Efficiency production of bioplastics from biodegradable organic solids. Journal of Polymers and the Environment. 2004; 12(2):89-94. http:// dx.doi.org/10.1023/B:JOOE.0000010054.58019.21
38. Bibers $\mathrm{K}$ and Kalnis M. Control of biopolymer poly- $\beta$-hydroxybutyrate characteristics by $\gamma$-irradiation. Mechanics of Composite Materials. 1999; 35(2):169-178. http://dx.doi.org/10.1007/BF02257247

39. Oliveira LM, Araujo ES and Guedes SML. Gamma irradiation effects on poly(hydroxybutyrate). Polymer Degradation and Stability. 2006; 91(9):2157-2162. http://dx.doi.org/10.1016/j. polymdegradstab.2006.01.008

40. Rabello MS and White JS. Fotodegradação do polipropileno: Um processo essencialmente heterogêneo. Polímeros. 1997; 47-57. 